\title{
State of the Art of Learning Analytics in Higher Education
}

\author{
Amita Dhankhar ${ }^{1}$, Kamna Solanki ${ }^{2}$ \\ ${ }^{1,2}$ University Institute of Engineering and Technology, Maharshi Dayanand University, Rohtak-124001, India \\ ${ }^{1}$ Amita.infotech@gmail.com, Kamna.mdurohtak@gmail.com
}

\begin{abstract}
One of the characteristics of our world today is that it is continuously changing. Every aspect of our world has been transformed by the emerging technologies, ranging from our day to day activities to scientific and industrial developments. This progress has been made in the last few decades. It is also true for all aspects of education. The use of emerging technologies at all levels of education, such as intelligent tutoring systems, learning management systems, interactive learning environments, and online learning, gives access to vast volumes of data of the students. Student data collected automatically in online learning environments are usually not converted into useful information for teaching, although it is a good source of information. It is poorly used throughout the educational domain. A new concept has emerged to capture this educational big data called "Learning Analytics". LA is about discovering hidden patterns in the educational process, assess student learning, and make predictions, which in turn provide a better understanding of teaching, learning, and interpretation of student's data. Higher education institutes are adapting to the evolving concept of LA. It would help HEI's to facilitates students to improve academic performance and enable teachers to keep track of individual students, identify student at-risk, and provide timely interventions. This paper provides the bird's eye view of the research evidence on the usage of learning analytics in higher education across the world by reviewing the leading publications, research studies, and case studies in this area.
\end{abstract}

Key words: Learning Analytics, Data-Driven Decisions, Higher Education Institution

\section{INTRODUCTION}

In the last couple of years, the rising interest in the multi-disciplinary and fast flourishing field of learning analytics is observable. This interest is motivated by digitization and the rapid change of technologies that provides an enormous amount of educational data. LA attempts to exploit this educational data "for purposes of understanding and optimizing learning and the environments in which it occurs" [1]. This field has originated from different fields like "business intelligence, web analytics, educational data mining, and recommender systems" [2]. LA also harnessed various methodologies and theories from statistics, computer science, and artificial intelligence [3]. In higher education, future developments in "technology-enhanced learning (TEL)" can be boosted by the implementation of LA [4-5]. Data is collected not only from classroom environments but also from educational software. This data will now act as a catalyst in the environment at the universities where the learning process is integrated with "virtual-learning environments (VLE)" [6]. When this data is analyzed, it will explore those pieces of information which earlier were "unseen, unnoticed, and therefore unactionable" [7]. When predictions were made on the basics of the research, these analytics have a significant impact in such a way that "more and better information is made available to a greater number of people, thus enabling informed decision-making" [8-9]. Earlier universities were hesitant to implement concepts of learning analytics because of various concerns related to data privacy, and concepts were missing on how it will be implemented, different stakeholder groups have conflicting interests. Now the scenario has changed, and LA has found its implementation in many universities. For future advancement and developments in learning analytics, policies are required to be made. This will thus enhance in making the learning process more efficient and productive, which will be beneficial in integrating it in higher education practice. The present study has collected and summarized information on the usage of learning analytics. Based on this study, the usage of learning analytics in the sector of higher education, and the anticipated benefits for higher education institutions can be identified. This research work collected the categorization of various case studies, empirical researches, as well as various learning analytics projects. Those are then summarized according to the institutes which have implemented learning analytics all over the globe concerning their purpose and the tool used.

\section{PANORAMA OF IMPLEMENTING LEARNING ANALYTICS IN HIGHER EDUCATION}

This section provides the status of implementation of LA projects/case studies among various higher education 
institutes across the world. The list is not exhaustive. These projects in higher education include tracking the learning progress of the student, teaching measures, and learning effectiveness. Various other includes providing early alerts and intercessions for improving operations and retentions, predicting the performance of students, personalizing their learning experience, making improvements in the process of testing and placement of students, improvement in resource allocation, and many more. The following subsections provide more detail of LA projects/case studies in various colleges and universities across different countries.

\subsection{Implementation of Learning Analytics in the USA}

Till now, the USA has implemented LA systematically and on a vast scale. Educause is a nonprofit association in the United States whose mission is "to advance higher education through the use of information technology." In 2012, it produced a report which describes and defines the risks which are linked with implementing (or not implementing) the learning analytics in the institutions of higher education [10]. The "Predictive Analytics Reporting (PAR) Framework is a non-profit provider of analytics-as-a-service to many various higher education institutions in the USA (two- and four-year courses of study, private and public, non-traditional and traditional institutions)." It aims to benchmark, prediction, and works towards understanding the risk signs advancement to completion. Apart from prediction, the aim of "PAR" is to provide support in identifying the good practices in the retention of the student through analysis of data, benchmarking across institutions, and shared models. The motivation for "PAR Framework" is double: a) To provide central analytics service with trained and skilled staff, covering various aspects of expertise ranging from the policy of data science to higher education practice so that cost incurred can be decreased; b) To provide valuable information on efficient strategies, by using cross $\square$ institutional benchmark studies so that progress, achievement, and engagement is obtained, which could not be revealed by the single-institution analytics activity [11]. Table 1 provides the existing practices and implementation of LA in American higher education.

Table 1: List of Universities implementing LA in the USA

\begin{tabular}{|c|c|c|c|c|}
\hline $\begin{array}{l}\text { Sr. } \\
\text { No. }\end{array}$ & Institute & $\begin{array}{c}\text { Projects/Case Studies/ } \\
\text { Tools/Pilots }\end{array}$ & Purpose & $\begin{array}{l}\text { Referenc } \\
\text { e No. }\end{array}$ \\
\hline 1. & $\begin{array}{lr}\text { University } & \text { of } \\
\text { Maryland } & \text { Eastern } \\
\text { Shore } & \end{array}$ & $\begin{array}{l}\text { Analytic Toolset: Microsoft } \\
\text { Performance and Microsoft SQL } \\
\text { Server }\end{array}$ & $\begin{array}{l}\text { "The dashboards can be personalized according } \\
\text { to the roles of end-users (e.g., faculty advisors, } \\
\text { administers, or support staff), Provide actual } \\
\text { data and targets for key performance indicators } \\
\text { specific to retention, admission, and progressive } \\
\text { advancement in an appropriate format." }\end{array}$ & {$[12]$} \\
\hline 2. & $\begin{array}{l}\text { Bowie } \\
\text { University }\end{array}$ & $\begin{array}{l}\text { Student Success Monitoring } \\
\text { System (SSMS). } \\
\text { Analytic Tool: Starfish Early } \\
\text { Alert/CONNECT }\end{array}$ & $\begin{array}{l}\text { Improve the retention and success of at-risk } \\
\text { students, also enhance the performance of all } \\
\text { retention support agents, including faculty, } \\
\text { advisers, counselors, retention coordinators, } \\
\text { and others, capturing real-time student data } \\
\text { related to any severe individual or } \\
\text { group-oriented student-retention effort. } \\
\text { Communicating the highlighted matters to } \\
\text { advisors, faculty, students, and other supporting } \\
\text { staff. }\end{array}$ & [13] \\
\hline 3. & $\begin{array}{l}\text { New York Institute of } \\
\text { Technology }\end{array}$ & Student At-Risk Model & $\begin{array}{l}\text { Developed its model and dashboard for } \\
\text { identifying at-risk students. }\end{array}$ & [14] \\
\hline 4. & $\begin{array}{l}\text { University of } \\
\text { Northern Arizona }\end{array}$ & Grade Performance Status (GPS) & $\begin{array}{l}\text { "Generate feedback alerts for academic } \\
\text { standing including attendance and academic } \\
\text { performance," personalized intervention, } \\
\text { Improved retention and graduation rates }\end{array}$ & [15] \\
\hline 5. & Paul Smith's College & $\begin{array}{l}\text { Comprehensive Student Support } \\
\text { Program. } \\
\text { Tool Used: "Rapid Insight's Veera } \\
\text { and Analytics programs, Starfish }\end{array}$ & $\begin{array}{l}\text { Early identification of At-Risk students. } \\
\text { Automatically prioritizing the students for } \\
\text { intervention and accessibility by support offices } \\
\text { and faculty }\end{array}$ & [16] \\
\hline
\end{tabular}




\begin{tabular}{|c|c|c|c|c|}
\hline & & $\begin{array}{llr}\text { Retention } & \text { Solutions } & \text { EARLY } \\
\text { ALERT } & \text { and } \text { CONNECT } \\
\text { programs." } & & \end{array}$ & & \\
\hline 6. & $\begin{array}{lr}\text { Rio } & \text { Salado } \\
\text { Community } & \text { College, } \\
\text { Arizona } & \end{array}$ & $\begin{array}{l}\text { "PACE (Progress and Course } \\
\text { Management)" }\end{array}$ & $\begin{array}{l}\text { Personalized Education for non-traditional } \\
\text { Students, Track Students Progress with } \\
\text { intervention. }\end{array}$ & [17] \\
\hline 7. & $\begin{array}{l}\text { Carnegie Mellon } \\
\text { University }\end{array}$ & OpenSimon: Toolkit & $\begin{array}{l}\text { Wide range of tools which can be useful to } \\
\text { classroom educators, Improve learning } \\
\text { outcomes for individual learners }\end{array}$ & [18] \\
\hline 8. & $\begin{array}{l}\text { Portland } \quad \text { State } \\
\text { University }\end{array}$ & DataMASTER & $\begin{array}{l}\text { Allow the extraction, organization, and analysis } \\
\text { of data from PSU enterprise data sources, } \\
\text { Facilitate the data-driven decision making }\end{array}$ & [19] \\
\hline 9. & Purdue University & Signals & $\begin{array}{l}\text { "Course Signals System Student alerts for } \\
\text { academic issues and provides intervention." }\end{array}$ & [20] \\
\hline 10. & $\begin{array}{l}\text { University } \\
\text { Michigan }\end{array}$ & $\begin{array}{l}\text { a). Gradecraft } \\
\text { b). My Learning Analytics } \\
\text { (MyLA) } \\
\text { c). E2Coach }\end{array}$ & $\begin{array}{l}\text { a). Use digital badges to provide motivating } \\
\text { Assessments } \\
\text { b). Provides information about student's } \\
\text { grades, assignments, engagement with course } \\
\text { material, and resource } \\
\text { c). Students support and intervention system, } \\
\text { Offer customized recommendations }\end{array}$ & [21-23] \\
\hline 11. & Ball State University & $\begin{array}{l}\text { Visualizing } \quad \text { collaborative } \\
\text { knowledge work } \\
\text { MAP-Works } \\
\text { Achievement Possible) }\end{array}$ & $\begin{array}{l}\text { Early identification of at-risk students, Early } \\
\text { interventions between teachers and first-year } \\
\text { students } \\
\text { Students gain insight about themselves; } \\
\text { Students recognize gaps between their behavior } \\
\text { and their expected outcomes }\end{array}$ & [24] \\
\hline 12. & Marist College & 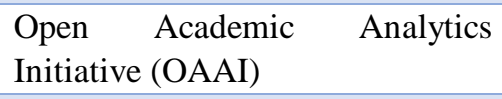 & $\begin{array}{l}\text { Predict students at-risk, Provide intervention to } \\
\text { students at-risk }\end{array}$ & [25] \\
\hline 13. & $\begin{array}{l}\text { Columbus State } \\
\text { Community College }\end{array}$ & Starfish, Blackboard & $\begin{array}{l}\text { Identify and track at-risk students, allow } \\
\text { instructors to record attendance }\end{array}$ & [26] \\
\hline 14. & $\begin{array}{l}\text { Youngstown State } \\
\text { University, Ohio }\end{array}$ & $\begin{array}{l}\text { EARS (Early Academic Report } \\
\text { System- formerly Starfish) }\end{array}$ & Improve graduation and completion rates & [27-28] \\
\hline 15. & Strayer University & $\begin{array}{l}\text { Civitas Learning's Student } \\
\text { Insight Platform }\end{array}$ & $\begin{array}{l}\text { Increase student and faculty engagement, } \\
\text { Improving behavioral mindsets }\end{array}$ & [29] \\
\hline 16. & $\begin{array}{l}\text { University of } \\
\text { Winsconsin Madison }\end{array}$ & $\begin{array}{l}\text { Lead Engagement } \text { Analytics } \\
\text { Dashboard (LEAD) }\end{array}$ & $\begin{array}{l}\text { Provide visualization in Tableau: Heatmap: - } \\
\text { "Shows when students are active in the course, } \\
\text { Scatter Plot: - maps grades and number of page } \\
\text { views." }\end{array}$ & [30] \\
\hline 17. & University of Hawaii & STAR & $\begin{array}{l}\text { Charting the academic pan of student's and } \\
\text { sending the alerts when students went off their } \\
\text { path }\end{array}$ & [31] \\
\hline 18. & $\begin{array}{l}\text { California State } \\
\text { University (Chico } \\
\text { State University) }\end{array}$ & $\begin{array}{l}\text { Chico State Learning Analytics } \\
\text { Research Project }\end{array}$ & $\begin{array}{l}\text { Study the relationship between LMS use and } \\
\text { achievement in academics. }\end{array}$ & [32] \\
\hline 19. & University of Phoenix & Predictive Analytic Model & Identify academically at-risk students & [33] \\
\hline 20. & $\begin{array}{l}\text { Grand } \quad \text { Rapids } \\
\text { Community College }\end{array}$ & $\begin{array}{l}\text { Advanced System Tracking } \\
\text { Reporting Online (ASTRO) }\end{array}$ & $\begin{array}{l}\text { Tracking, identify key faculty, upgrade } \\
\text { planning, advanced reporting }\end{array}$ & [34] \\
\hline 21. & $\begin{array}{l}\text { Austin Peay State } \\
\text { University }\end{array}$ & Degree Compass & Provide course recommendation & [35] \\
\hline 22. & $\begin{array}{l}\text { Texas A\&M } \\
\text { University-San } \\
\text { Antonio }\end{array}$ & $\begin{array}{l}\text { CourseSmart digital textbook } \\
\text { analytics }\end{array}$ & $\begin{array}{l}\text { Effective early warning system, identify a } \\
\text { student at risk }\end{array}$ & [36] \\
\hline 23. & Manson & Survival Analysis framework & Identify at-risk students, provide intervention, & [37] \\
\hline
\end{tabular}


Amita Dhankhar et al., International Journal of Emerging Trends in Engineering Research, 8(3), March 2020,868 - 877

\begin{tabular}{|c|c|c|c|c|}
\hline & University & & predict students who drop out and when dropout & \\
\hline 24. & $\begin{array}{l}\text { Sinclair Community } \\
\text { College }\end{array}$ & $\begin{array}{llll}\text { Student } & \text { Success } & \text { Plan } & \text { (SSP)- } \\
\text { Project } & & & \end{array}$ & $\begin{array}{l}\text { Provides a holistic case management system } \\
\text { used by teachers and support staff in helping } \\
\text { students to complete college }\end{array}$ & [38] \\
\hline 25. & $\begin{array}{ll}\text { Georgia } & \text { State } \\
\text { University } & \end{array}$ & Predictive Analytics & $\begin{array}{l}\text { Eliminating the gap in graduation rates between } \\
\text { low-income and minority students and the rest } \\
\text { of the student body }\end{array}$ & [39] \\
\hline 26. & $\begin{array}{l}\text { University of } \\
\text { Kentucky }\end{array}$ & SAP's HANA & $\begin{array}{l}\text { Provide real-time insight into student's } \\
\text { behavior and success }\end{array}$ & {$[40]$} \\
\hline 27. & $\begin{array}{l}\text { University of } \\
\text { Lynchburg, Virginia }\end{array}$ & Student Retention Predictor (SRP) & Identifies and priorities group of at-risk students & [41] \\
\hline 28. & Harvard University & Learning Catalytics & $\begin{array}{l}\text { To provide learners with customized support to } \\
\text { boost the efficient collaboration between } \\
\text { learners and enabling the instructors to } \\
\text { fine-tune instructional practices }\end{array}$ & [42-43] \\
\hline 29. & Capella University & $\begin{array}{l}\text { Fully Embedded Assessment } \\
\text { Model (FEAM) }\end{array}$ & Learning and Career outcomes & [44] \\
\hline
\end{tabular}

\subsection{Implementation of Learning Analytics in the UK}

Numerous institutions in the UK are deploying learning analytics in diverse ways and for various reasons. In the United Kingdom, the work of Jisc (formerly the Joint Information Systems Committee) has made considerable progress in LA with the establishment of a national learning analytics service for higher and further education. Working and collaborating with 50 universities, Jisc has developed a suite of resources, tools, and guides to support the implementation of LA in the UK [45]. The research concluded that those who have earlier adopted this for enhancing the learning experience of students are due to several reasons. Those reasons include improving the chances for achievement, providing better feedback, and boosting students so that they may become brilliant learners. Retention may be a significant issue for some institutions, and they use learning analytics for identifying the students who are at risk of dropout. However, retention is not a significant problem for others. One of the crucial drivers mentioned is providing students better information about their progress. As per the current scenario internationally and in the UK also, Jisc anticipates that LA can make a significant contribution for; quality assurance and quality improvement, boosting retention rates, assessing and acting on differential outcomes for students, and as an enabler for the introduction of adaptive learning.

Table 2: List of Universities implementing LA in the UK

\begin{tabular}{|c|c|c|c|c|}
\hline $\begin{array}{l}\text { Sr. } \\
\text { No. }\end{array}$ & Institute & Projects/ Case Studies/ Tools/Pilots & Purpose & $\begin{array}{l}\text { Referenc } \\
\text { e No. }\end{array}$ \\
\hline 1. & The Open University & $\begin{array}{l}\text { a). OU Analyses Project } \\
\text { b). Analytics4Action Evaluation } \\
\text { Framework } \\
\text {,c). OpenEssayist }\end{array}$ & $\begin{array}{l}\text { a). Provide early prediction of 'at-risk' students so that } \\
\text { meaningful and 'cost-effective' intervention can be } \\
\text { provided. } \\
\text { b). Translate the insights from learning analytics into } \\
\text { actionable interventions. } \\
\text { c). tool for learner support, analytics for assessment, } \\
\text { provide description and summary for visualization }\end{array}$ & {$[46-48]$} \\
\hline 2. & $\begin{array}{l}\text { University } \\
\text { Edinburgh }\end{array}$ & $\begin{array}{l}\text { Learning Analytics Report Card (LARC) } \\
\text { (Project) }\end{array}$ & $\begin{array}{l}\text { Presents a summary of student's academic progress in } \\
\text { textual and visual form }\end{array}$ & [49] \\
\hline 3. & University of Derby & $\begin{array}{l}\text { D2L's Brightspace VLE, } \\
\text { Experience } \\
\text { (SETL)-Project }\end{array}$ & $\begin{array}{l}\text { Easy to learn } \\
\text { Provide invaluable insight through data analytics } \\
\text { capabilities, Automates the delivery of courses, Track } \\
\text { learners progress, Tailored to each learner's lifestyle }\end{array}$ & {$[50-51]$} \\
\hline 4. & $\begin{array}{l}\text { University } \\
\text { Nebraska-Lincoln }\end{array}$ & Hobsons Starfish Early Alert & Identify Struggling students, Support at-risk students. & {$[52]$} \\
\hline 5. & Nottingham Trent & Dashboard & Send e-mail alert to instructors when student & [53] \\
\hline
\end{tabular}


Amita Dhankhar et al., International Journal of Emerging Trends in Engineering Research, 8(3), March 2020, 868 - 877

\begin{tabular}{|c|c|c|c|c|}
\hline & University & & engagement stops for two weeks & \\
\hline 6. & $\begin{array}{l}\text { University of } \\
\text { Bedfordshire }\end{array}$ & $\begin{array}{l}\text { "Strategic ICT for Managing Student } \\
\text { Engagement (SIMSE) project } \\
\text { JICS's Strategic Toolkit } \\
\text { Improved Student Engagement System } \\
\text { (SES)" }\end{array}$ & Students progression and retention, Tailored guidance & {$[54]$} \\
\hline 7. & Bridgwater College & ProMonitor, ProSolution & $\begin{array}{l}\text { Attendance reports and retention at the level of } \\
\text { individual, program and college, e-mails/letters sent to } \\
\text { students/parents if the deadline has been missed or } \\
\text { attendance is unsatisfactory }\end{array}$ & [55] \\
\hline 8. & $\begin{array}{l}\text { The University of East } \\
\text { London }\end{array}$ & QlikView & $\begin{array}{l}\text { Automated e-mails sent to students every month } \\
\text { showing their attendance }\end{array}$ & {$[55]$} \\
\hline 9. & Lancaster University & Tableau & $\begin{array}{l}\text { Interactive Transcript help instructors to give better } \\
\text { advice to students }\end{array}$ & {$[55]$} \\
\hline 10. & $\begin{array}{l}\text { Loughborough } \\
\text { University }\end{array}$ & Co-Tutor & $\begin{array}{l}\text { "Software creates dashboards and exactly alerts for } \\
\text { different tutoring roles and provides an audit trail of } \\
\text { their interaction with students, to escalate issues, } \\
\text { automatic messages and notifications are passed." }\end{array}$ & {$[55]$} \\
\hline 11. & $\begin{array}{l}\text { Manchester } \\
\text { Metropolitan } \\
\text { University }\end{array}$ & $\begin{array}{l}\text { Enhance Quality and Assessment for } \\
\text { learning (EQAL) program, Programme } \\
\text { leader dashboard }\end{array}$ & $\begin{array}{l}\text { Personalized information to students, "Continuous } \\
\text { Monitoring and Improvement (CMI) system, Student } \\
\text { Engagement Monitoring (SEM)" }\end{array}$ & [55] \\
\hline 12. & $\begin{array}{l}\text { Oxford } \quad \text { Brookes } \\
\text { University }\end{array}$ & $\begin{array}{l}\text { Academic Performance Tracking Tools, } \\
\text { Dashboard, Qlikview }\end{array}$ & $\begin{array}{l}\text { The tool used for module program and faculty review } \\
\text { and overall operational plan for university }\end{array}$ & {$[55]$} \\
\hline 13. & $\begin{array}{l}\text { University of } \\
\text { Wolverhampton }\end{array}$ & Tribal's Student Insights & $\begin{array}{l}\text { Predict student risk, focus on retention and academic } \\
\text { performance risk }\end{array}$ & {$[56]$} \\
\hline 14. & $\begin{array}{l}\text { University of } \\
\text { Northampton }\end{array}$ & $\begin{array}{l}\text { Projects -LEARN (Learner Engagement } \\
\text { Attendance \& Retention at } \\
\text { Northampton) Student Analytic } \\
\text { dashboard } \\
\text { Active Blended Learning } \\
\text { ChANGE (Changemaker Attributes at } \\
\begin{array}{l}\text { Northampton for } \\
\text { Employability) }\end{array}\end{array}$ & $\begin{array}{l}\text { Track student's engagement in the course, help } \\
\text { instructors to support student success }\end{array}$ & [57-60] \\
\hline 15. & Swansea University & Unitu & $\begin{array}{l}\text { Provide online space where students, instructors and } \\
\text { supporting staff talk and resolve academic and non- } \\
\text { academic issues, improve student's engagement }\end{array}$ & [61] \\
\hline 16. & Coventry University & $\begin{array}{l}\text { EdTech startup: Aula } \\
\text { Learning Analytics Dashboards (LAD) } \\
\text { Learning and study strategies Inventory } \\
\text { (LASSI) }\end{array}$ & Student engagement through social learning & {$[62]$} \\
\hline
\end{tabular}

\subsection{Implementation of Learning Analytics in Australia}

Australian people do some of the most interesting innovations. They have carried out extensive work on learning analytics. Interesting largescale practices are described in a report called "Student retention and learning analytics: A snapshot of Australian practices and a framework for advancement" [63]. One of the project 'Loop' targeted the practical problem of how to better support effective teaching and student learning online and understand the needs and perceptions of teachers in higher education to ensure that learning analytics can be genuinely useful in teaching and learning practice [70]. To enhance the teaching and learning at Wollongong [69], various studies are there which are related to the usage of social network analysis. The role of analytics is examined to help in planning by students through their modules at "Open Universities Australia (OUA)" [68]. 
Table 3: List of Universities implementing LA in Australia

\begin{tabular}{|c|c|c|c|c|}
\hline $\begin{array}{l}\text { Sr. } \\
\text { No. }\end{array}$ & Institute & $\begin{array}{l}\text { Projects/ Case Studies/ } \\
\text { Tools/Pilots }\end{array}$ & Purpose & $\begin{array}{l}\text { Referenc } \\
\text { e No. }\end{array}$ \\
\hline 1. & Edith Cowan University & Tool: C4S & $\begin{array}{l}\text { Improve student engagement, Enhancing } \\
\text { retention }\end{array}$ & [64] \\
\hline 2. & University of New England & $\begin{array}{l}\text { Automated Wellness Engine } \\
\text { (AWE) } \\
\text { Dashboards-- e-Motion, The Vibe }\end{array}$ & $\begin{array}{l}\text { For identification of high-risk learners, an } \\
\text { Evidence-based system of retention is used. For } \\
\text { enhancing the learner retention and engagement } \\
\text { and early alert, the engine is designed }\end{array}$ & [65] \\
\hline 3. & The University of Adelaide & Teamwork DashBoard & $\begin{array}{l}\text { Monitoring teams in real-time for CS students for } \\
\text { their role in problem-solving is done by the } \\
\text { educators, team projects. Feedback about team } \\
\text { interactions is provided by educators using } \\
\text { Teamwork Dashboard, Identify problematic } \\
\text { team. }\end{array}$ & [66] \\
\hline 4. & University of Sydney & Tool developed -PASTA & $\begin{array}{l}\text { Provide instant feedback for students and } \\
\text { auto-grading for teachers }\end{array}$ & [67] \\
\hline 5. & Open Universities, Australia & $\begin{array}{l}\text { Personalized Adaptive Study } \\
\text { Success (PASS) }\end{array}$ & $\begin{array}{l}\text { Identify student at risk, Personalization of the } \\
\text { study experience for each student, suggest } \\
\text { alternative modules to struggling students }\end{array}$ & [68] \\
\hline 6. & University of Wollongong & $\begin{array}{l}\text { SNAPP (The Social Networks } \\
\text { Adapting Pedagogical Practice) }\end{array}$ & $\begin{array}{l}\text { Evaluate students' behavioral pattern and } \\
\text { provide the best practice }\end{array}$ & [69] \\
\hline 7. & University of Melbourne & Loop Tool & $\begin{array}{l}\text { Enable teachers to articulate their learning, and } \\
\text { Data is represented via visual representations } \\
\text { from the LMS }\end{array}$ & [70] \\
\hline 8. & Macquaire University & Loop Tool & $\begin{array}{l}\text { Enable teachers to articulate their learning, and } \\
\text { Data is represented via visual representations } \\
\text { from the LMS }\end{array}$ & [70] \\
\hline 9. & University of South Australia & Loop Tool & $\begin{array}{l}\text { Enable teachers to articulate their learning, and } \\
\text { Data is represented via visual representations } \\
\text { from the LMS }\end{array}$ & [70] \\
\hline
\end{tabular}

\subsection{Implementation of Learning Analytics in European Countries}

Europe has seen an enormous surge in the research being conducted in learning analytics, especially from countries such as Netherlands, UK, Germany, Spain, Austria. Additionally, several European countries, such as the Netherlands, Norway, and Denmark, are developing nationwide learning analytics strategies that include national policies, infrastructure, and competence centers. Many ongoing European-funded projects are given below:

FP7-funded projects: "LACE (Learning analytics community exchange)" [71], "LEA's Box (Learning analytics toolbox)" [72], "PELARS (Practice-based experiential learning analytics research and support)" [73], "PERICLES (Promoting and Enhancing Reuse of Information throughout the Content Lifecycle taking account of Evolving Semantics)" [74].
Erasmus+funded projects: "PBL3.0 (Integrating learning analytics and semantics in problem-based learning)" [75], "SHEILA (Supporting higher education to incorporate learning analytics)" [76], "STELA (Successful transition from secondary to higher education through learning analytics)" [77].

JRC Funded "LAEP (Implications and opportunities for learning analytics for European educational policy)" [78].

H2020 funded Project: "RAGE (Realizing an applied gaming ecosystem)" [79].

Innovation Fund Denmark funded projects: GBL21 (Game-based Learning in the 21st Century) [80]. ATEL (Automatically Tracking Early Stage Literacy Skills) [81].

Table 4: List of Universities implementing LA in European Countries 


\begin{tabular}{|c|c|c|c|c|}
\hline $\begin{array}{l}\text { Sr. } \\
\text { No. }\end{array}$ & Institute & $\begin{array}{c}\text { Projects/ Case Studies/ } \\
\text { Tools/Pilots }\end{array}$ & Purpose & $\begin{array}{l}\text { Reference } \\
\text { No. }\end{array}$ \\
\hline 1. & University of Salamanca (Spain) & $\begin{array}{l}\text { Virtual e-Learning Analytics } \\
\text { System (study) }\end{array}$ & $\begin{array}{l}\text { Facilitate Visualization, help in decision making, } \\
\text { Improve education processes }\end{array}$ & {$[82]$} \\
\hline 2. & $\begin{array}{l}\text { Open University of Catalonia } \\
\text { (Spain) }\end{array}$ & $\begin{array}{l}\text { Automated System for Inferring } \\
\text { Relevant Topics for Each Subject }\end{array}$ & $\begin{array}{l}\text { "Used for analyzing the suitability of materials to } \\
\text { subjects, Allows better understanding of subjects } \\
\text { Enrich and contextualize other analytical } \\
\text { processes." }\end{array}$ & [83] \\
\hline 3. & $\begin{array}{l}\text { Dublin City University, Ireland } \\
\text { (Europe) }\end{array}$ & PredictED & $\begin{array}{l}\text { Uses past and present log data to predict outcomes } \\
\text { weekly basis, Generate automated personalized } \\
\text { e-mails to students at-risk }\end{array}$ & [84] \\
\hline 4. & KU Leuven, Belgium & $\begin{array}{l}\text { a. LASSI } \\
\text { b. REX }\end{array}$ & $\begin{array}{l}\text { a. Provide actionable feedback about five learning } \\
\text { skills accessed by LASSI concentration, anxiety, } \\
\text { motivation, test strategies, time management } \\
\text { b. Provide Feedback on academic achievement }\end{array}$ & [85] \\
\hline 5. & TU Delft, Netherland & $\begin{array}{l}\text { a. LASSI } \\
\text { b. REX }\end{array}$ & $\begin{array}{l}\text { a. Provide actionable feedback about five learning } \\
\text { skills accessed by LASSI concentration, anxiety, } \\
\text { motivation, test strategies, time management } \\
\text { b. Provide Feedback on academic achievement }\end{array}$ & {$[86]$} \\
\hline 6. & $\begin{array}{l}\text { Ulster University, Northern } \\
\text { Ireland }\end{array}$ & Blackboard Predict & To help identify students at-risk & [87] \\
\hline 7 & $\begin{array}{l}\text { RWTH Aachen University } \\
\text { (Germany) }\end{array}$ & $\begin{array}{l}\text { eLAT (a Learning Analytics } \\
\text { Toolkit) }\end{array}$ & $\begin{array}{l}\text { Support faculty evaluation, Indicator, and } \\
\text { visualization of specific data }\end{array}$ & \\
\hline
\end{tabular}

Table 5: List of other Universities implementing LA

\begin{tabular}{|c|c|c|c|c|}
\hline $\begin{array}{l}\text { Sr. } \\
\text { No. }\end{array}$ & Institute & $\begin{array}{l}\text { Projects/ Case Studies/ } \\
\text { Tools/Pilots }\end{array}$ & Purpose & $\begin{array}{l}\text { Referenc } \\
\text { e No. }\end{array}$ \\
\hline 1. & $\begin{array}{l}\text { University of North Bengal } \\
\text { (India)(study) }\end{array}$ & $\begin{array}{l}\text { Determine the predictors } \\
\text { of dropouts }\end{array}$ & $\begin{array}{l}\text { Provide valuable guidance for counselors and faculty } \\
\text { members to educate learners for the best possible } \\
\text { completion options. }\end{array}$ & {$[88]$} \\
\hline 2. & $\begin{array}{l}\text { University of British Columbia } \\
\text { (Canada) }\end{array}$ & $\begin{array}{l}\text { a. OnTask } \\
\text { b. VizIT } \\
\text { c. Threadz }\end{array}$ & $\begin{array}{l}\text { a.Provide timely personalized and actionable feedback to } \\
\text { learners } \\
\text { b.helps instructors stay informed about learner activity in } \\
\text { edX } \\
\text { c.Allows instructors to visualize the social dynamics of } \\
\text { discussion forums }\end{array}$ & [89] \\
\hline 3. & University of South Pacific, Fiji & $\begin{array}{l}\text { Framework for } \\
\text { development of an open } \\
\text { textbooks analytics system }\end{array}$ & $\begin{array}{l}\text { Enables the recording, analysis, and presentation of } \\
\text { interactional data that is generated by student interactions } \\
\text { with open textbooks }\end{array}$ & [90] \\
\hline
\end{tabular}

\section{CONCLUSION}

Learning analytics (LA) has enabled providers to develop new ways of achieving excellence in teaching and learning. It has helped students to make the best choice about their education. LA will aid in developing more student-focused programs of higher education. It also provides tools and data to the institutions which may be required for making continuous improvements. The usage of digital tools enhances the learning process. Various projects/case studies from LA revealed how, with the usage of these tools,' student's learning is optimized and has proven to be beneficial for institutions, teachers, and students. After going through the available literature, this study observes that there is a positive response to the usage of LA. In this paper, the evidence on the implementation of LA in higher education across the world is gathered. It can be seen from the study that proper research and practice in the field of LA has been seen in the USA, Australia, UK, and other European countries. Most of the work has been limited to the use of prediction and data models to identify student's at- risk so that timely support can be provided. LA could play a significant role in supporting other essential areas like wellbeing, innovation, and employability. There are various emergent aspects as well, such as developing an open education system, lifelong learning, and spreading of education internationally. Owing 
to the prevailing trend of digitalization, LA supports the emergence of the online education system. LA has addressed various challenges faced by higher education institutions. Within an institution, LA is not just a technological/development or a research issue but an organizational issue as well. Various challenges, privacy, and ethical issues are faced while collecting the data of the students. They are thus considered carefully and addressed according to the institution and cultural context. This study has summarized the findings on LA for different projects/case studies that are going on in different countries and institutions. Implementation of LA in higher education can be seen as promising. Although the field of LA is still in its infancy. Various unexplored and underexplored areas exist in the projects/case studies, and the researchers in the future could explore them.

\section{REFERENCES}

1. Long, P. D., \& Siemens, G. (2011). Penetrating the fog: Analytics in learning and education. EDUCAUSE Review, 46(5), 31-40.

2. Ferguson, R. (2012). Learning analytics: drivers, developments, and challenges. International Journal of Technology Enhanced Learning, 4(5/6), 304-317. https://doi.org/ 10.1504/ijtel.2012.051816.

3. Siemens G, d Baker RS (2012) Learning analytics and educational data mining: towards communication and collaboration. In: Proceedings of the 2 nd international conference on learning analytics and knowledge, ACM, pp 252-254. https://doi.org/10.1145/2330601.2330661

4. Johnson, L., R. Smith, H. Willis, A. Levine, and K. Haywood. 2011. "NMC Horizon Report: 2011 Higher Education Edition". Austin, Texas.

5. Johnson, L., S. Adams, and M. Cummins. 2012. "NMC Horizon Report: 2012 Higher Education Edition”. Austin, Texas.

6. Romero, Cristóbal, Sebastián Ventura, Mykola Pechenizkiy, and Ryan S.J.d. Baker, ed. 2011. Handbook of Educational Data Mining. Boca Raton, London, New York: Chapman \& Hall, CRC Data Mining and Knowledge Discovery Series

7. Cator, Karen, and Bernadette Adams. 2012. "Enhancing Teaching and Learning Through Educational Data Mining and Learning Analytics: An Issue Brief." Washington, DC.

8. Campbell, John P., Peter B. DeBlois, and Diana Oblinger. 2007. "Academic Analytics: A New Tool for A New Era.” EDUCAUSE Review 42 (4): 40-57.

9. A. Dhankhar, K. Solanki, A. Rathee and Ashish, "Predicting Student's Performance by using Classification Methods," International Journal of advanced trends in computer science and engineering, Volume 8 No. 4, 2019.
10. http://bit.ly/1Z8NRtE

11. http://www.parframework.org/about-par/overview/

12. https://er.educause.edu/articles/2012/8/two-case-studies -of-learner-analytics-in-the-university-system-of-maryla nd

13. Fabio Chacon, Donald Spicer, and Al Valbuena. "Analytics in Support of Student Retention and Success" (Research Bulletin 3, 2012). Louisville, CO: EDUCAUSE Center for Analysis and Research, 2012, available from http://www.educause.edu/ecar.

14. Sclater, N., Peasgood, A. and Mullan, J. (2016), "Learning analytics in higher education: a review of UK and international practice," available at: www.jisc.ac.uk/reports/learning-analytics-in-higher-ed ucation

15. Star, M. and Collette, L. (2010), “GPS: shaping student success one conversation at a time," EDUCAUSE, available at http://er.educause.edu/articles/2010/12/gps-shaping-stu dent-success-one-conversation-at-a-time

16. McAleese, V. and Taylor, L. (2012), "Beyond retention: using targeted analytics to improve student success," EDUCAUSE Review, 17 July, available http://er.educause.edu/articles/2012/7/beyond-retentionusing-targeted-analytics-to-improve-student-success

17. Crush, M. "Monitoring the PACE of Student Learning: Analytics at Rio Salado Community College. Campus Technology (December 14, 2011."

18. https://www.cmu.edu/simon/open-simon/

19. Blanton, S.E. (2012), "Datamaster: success and failure on a journal of business intelligence," EDUCAUSE case studies, available at http://er.educause.edu/articles/2012/7/datamaster-succe ss-and-failure-on-a-journey-to-business-intelligence

20. Arnold, K.E., and Pistilli, M.D. (2012), "Course signals at Purdue: using learning analytics to increase student success," The 2nd International Conference on Learning Analytics and Knowledge, Vancouver, pp. 267-270.

21. https://gradecraft.com/

22. https://its.umich.edu/academics-research/teaching-learn ing/my-learning-analytics

23. McKay, T., Miller, K., \& Tritz, J. (2012) "What to do with actionable intelligence: E2Coach as an intervention engine". Retrieved from http://sitemaker.umich.edu/ecoach/files/lak_2012_subm ission.pdf

24. Jones, D. and Woosley, S. (2011), "The foundation of MAP-Works: research and theoretical underpinnings of MAP-Works," Educational Benchmarking (EBI), available at www2.indstate.edu/studentsuccess/pdf/The Foundation of MAP-Works.pdf

25. Jayaprakash, S.M., Moody, E.W., Lauria, E.J.M., Regan, R. and Baron, J.D. (2014), "Early alert of academically at-risk students: an open-source 
Amita Dhankhar et al., International Journal of Emerging Trends in Engineering Research, 8(3), March 2020, 868 - 877

analytics initiative," Journal of Learning Analytics, Vol. 1 No. 1, pp. 6-47

https://doi.org/10.18608/jla.2014.11.3

26. https://www.cscc.edu/services/starfish/

27. https://ysu.edu/it-customer-services/starfish

28. https://www.hobsons.com/resources/entry/youngstownstate-university-adopts-the-starfish-system-to-support-c ampus-in

29. https://www.civitaslearning.com/press/strayer-universit y-applies-predictive-analytics-improve-student-successonline-education/

30. https://at.doit.wisc.edu/evaluation-design-analysis/learn ing-analytics-projects/

31. https://www.star.hawaii.edu:10012/studentinterface

32. . http://tinyurl.com/acz5f7o

33. Barber, R., \& Sharkey, M. (2012). Course correction: Using analytics to predict course success. Proceedings of the 2nd International Conference on Learning Analytics and Knowledge (LAK'12), Vancouver, Canada, 29 April-2 May, New York, NY: Association of Computer Machinery, 259- 262. DOI:10.1145/2330601.2330664

34. http://projects.oscelot.org/gf/project/astro

35. Denley, Tristan (2012), 'Austin Peay State University: Degree Compass' in Oblinger, Diana, (ed.) Game Changers: Education and Information Technologies. Educause, 2012.

36. Junco, R., \& Clem, C. (2015). Predicting course outcomes with digital textbook usage data. The Internet and Higher Education, 27, 54-63. DOI: 10.1016/j.iheduc.2015.06.001

37. Yujing Chen, Aditya Johri, and Huzefa Rangwala. 2018. Running out of STEM: a comparative study across STEM majors of college students at-risk of dropping out early. In Proceedings of the 8th International Conference on Learning Analytics and Knowledge (LAK '18). Association for Computing Machinery, New York, NY, USA, 270-279. DOI: https://doi.org/10.1145/3170358.3170410

38. https://er.educause.edu/articles/2011/12/the-student-suc cess-plan-case-management-and-intervention-software

39. https://sr.ithaka.org/wp-content/uploads/2015/08/SR_C ase_Study_Building_Pathway_Student_Success_04231 5_0.pdf

40. https://tdwi.org/articles/2018/04/10/adv-all-university-o f-kentucky-analytics-student-success-factors.aspx

41. https://www.ruffalonl.com/papers-research-higher-educ ation-fundraising/lynchburg-college-virginia/

42. Leveraging Analytics in Community Colleges by Treca Stark, Published Monday, September 14, 2015, on the Educause website

43. http://atg.fas.harvard.edu/learning-catalytics

44. https://www.learningoutcomesassessment.org/documen ts/CapellaUniversityCaseStudy.pdf

45. https://www.jisc.ac.uk/rd/projects/effective-learning-an alytics
46. Kuzilek, Jakub; Hlosta, Martin; Herrmannova, Drahomira; Zdrahal, Zdenek; Vaclavek, Jonas and Wolff, Annika (2015). OU Analyse: analysing at-risk students at The Open University. Learning Analytics Review, LAK15-1 pp. 1-16.

47. Rienties, B., Boroowa, A., Cross, S., Kubiak, C., Mayles, K. and Murphy, S. (2016), "Analytics4action evaluation framework: a review of evidence-based learning analytics interventions at the Open University UK", Journal of Interactive Media in Education, Vol. 1 No. 2, pp. 1-13.

48. Whitelock, Denise; Twiner, Alison; Richardson, JohnT.E.; Field, DeboraandPulman, Stephen(2015). OpenEssayist: a supply and demand learning analytics tool for drafting academic essays. In: Proceedings of the Fifth International Conference on Learning Analytics And Knowledge, ACM, pp. 208-212.

49. https://larcproject.wordpress.com/

50. https://www.d21.com/newsroom/releases/university-der by-selects-d21s-brightspace-vle-modern-design-personal ised-learning-analytics-capabilities/

51. http://repository.jisc.ac.uk/5657/1/Learning_analytics_r eport.pdf

52. https://www.hobsons.com/res/Case_Studies/UNLCaseSt udy_Final.pdf

53. https://analytics.jiscinvolve.org/wp/files/2016/04/CASE -STUDY-I-Nottingham-Trent-University.pdf

54. https://jiscinfonetcasestudies.pbworks.com/w/page/6819 4223/Transformations\%20University\%20of\%20Bedfor dshire

55. http://repository.jisc.ac.uk/5657/1/Learning_analytics_r eport.pdf

56. http://analytics.jiscinvolve.org/wp/2014/10/27/tribal-stu dent-insight-an-interview-with-chris-ballard/

57. https://www.northampton.ac.uk/ilt/current-projects/lear $\mathrm{n} /$

58. https://www.northampton.ac.uk/ilt/current-projects/cha nge/

59. https://www.northampton.ac.uk/ilt/current-projects/abl/

60. https://ji.sc/transform_spaces

61. http://repository.jisc.ac.uk/7473/3/edtech-case-study-sw ansea.pdf

62. http://repository.jisc.ac.uk/7473/1/edtech-case-study-co ventry.pdf

63. Colvin, C., Rogers, T., Wade, A., Dawson, S., Gasevic, D., Buckingham Shum, S., ... \& Corrin, L. (2016). Student retention and learning analytics: A snapshot of Australian practices and a framework for advancement.

64. Jackson, G. \& Read, M. (2012). Connect 4 Success: A Proactive Student Identification and Support Program. ECU: Australia, 1-5. Retrieved from fyhe.com.au/past_papers/papers12/Papers/9B.pdf

65. Leece, R. \& Hale, R. (2009). Student Engagement and Retention through e-Motional Intelligence. UNE: Australia. Retrieved from 
http://www.educationalpolicy.org/events/R09/PDF/Leec e_E-Motion.pdf

66. Tarmazdi, H., Vivian, R., Szabo, C., Falkner, K. and Falkner, N. (2015), "Using learning analytics to visualise computer science teamwork," The 2015 ACM Conference on Innovation and Technology in Computer Science Education, Vilnius, pp. 165-170

67. Gramoli, V., Charleston, M., Jeffries, B., Koprinska, I., McGrane, M., Radu, A., Viglas, A. and Yacef, K. (2016), "Mining autograding data in computer science education," The Eighteenth Australasian Computing Education Conference, Canberra, 1-5 February, available at http://dl.acm.org/citation.cfm?id=2843070

68. Atif, A., Richards, D., Bilgin, A. and Marrone, M. (2013), "A panorama of learning analytics featuring the technologies for the learning and teaching domain," The 30th Ascilite Conference, Sydney, pp. 68-72.

69. Bakharia, A. \& Dawson, S. (2011). SNAPP: A Bird's-Eye View of Temporal Participant Interaction. Proceedings of the 1st International Conference on Learning Analytics and Knowledge, 168-173.

70. Corrin, L., Kennedy, G., de Barba, P.G., Lockyer, L., Gašević, D., Williams, D., Dawson, S., Mulder, R., Copeland, S., \& Bakharia, A. (2016). Completing the Loop: Returning Meaningful Learning Analytic Data to Teachers. Sydney: Office for Learning and Teaching

71. http://www.laceproject.eu/

72. http://www.leas-box.eu/

73. http://www.pelars.eu/

74. https://cordis.europa.eu/project/id/601138

75. https://www.ou.nl/web/welten-research/pbl3.0

76. http://bit.ly/1T46Zoq

77. http://bit.ly/1Mz5jMW

78. http://bit.ly/1Xu9v6E

79. http://rageproject.eu/

80. (https://gbl21.aau.dk

81. Nouri, J., Ebner, M., Ifenthaler, D., Saqr, M., Malmberg, J., Khalil, M., ... \& Berthelsen, U. D. (2019). Efforts in Europe for Data-Driven Improvement of Education-A Review of Learning Analytics Research in Seven Countries. International Journal of Learning Analytics and Artificial Intelligence for Education (iJAI), 1(1), 8-27.

82. Conde, M.A., Garcia-Penalvo, F.J., Gomez-Aguilar, D. and Theron, R. (2015), "Exploring software engineering subjects by using visual learning analytics techniques", IEEE Revista Iberoamericana De Tecnologias Del Aprendizaje, Vol. 10 No. 4, pp. 242-252.

83. Guitart, I., More, J., Duran, J., Conesa, J., Baneres, D. and Ganan, D. (2015), "A semi-automatic system to detect relevant learning content for each subject," The 7th International Conference on Intelligent
Networking and Collaborative Systems, Taipei, pp. 301-307.

84. https://www.dcu.ie/teu/projects.shtml

85. Broos, T., Peeters, L., Verbert, K., Van Soom, C., Langie, G., \& De Laet, T. (2017). Dashboard for actionable feedback on learning skills: How learner profile affects use. In Proceedings of the 7th Workshop on Awareness and Reflection in Technology Enhanced Learning Co-located With the 12th European Conference on Technology Enhanced Learning (EC-TEL 2017) (Vol. 1997, pp. 1-15). CEUR Workshop Proceedings.

86. https://www.jisc.ac.uk/reports/the-future-of-data-driven -decision-making

87. https://learninganalytics.ubc.ca/about-the-project/tool-p ilots/

88. Yasmine, D. (2013), "Application of the classification tree model in predicting learner dropout behaviour in open and distance learning," Distance Education, Vol. 34 No. 2, pp. 218-231.

89. Prasad, D., Totaram, R. and Usagawa, T. (2016), "Development of open textbooks learning analytics system," International Review of Research in Open and Distributed Learning, Vol. 17 No. 5, pp. 215-234. https://doi.org/10.19173/irrodl.v17i5.2541

90. L. Dyckhoff, S. Zieke, M Bultmann, M. A Chatti, U. Schroeder. Design and Implementation of a Learning analytics Toolkit for Teachers, Educational Technology \& Society, 2012. 